\title{
PERANCANGAN SISTEM INFORMASI PENYEWAAN DAN PEMBAYARAN ALAT KATERING PADA VIAA WEDDING
}

\author{
Eva Dwi Afriyanti ${ }^{1}$, Lusi Ariyani ${ }^{2}$, Luh Putu Widya Adnyani ${ }^{3}$ \\ Program Studi Teknik Informatika, Fakultas Teknik dan Ilmu Komputer, \\ Universitas Indraprasta PGRI \\ Jalan Raya Tengah No 80, Kelurahan Gedong, Pasar Rebo, Jakarta Timur \\ evadwiafriyanti02@gmail.com ${ }^{1}$, lusiaryani0312@gmail.com², aluhputuwidya@gmail.com ${ }^{3}$
}

\begin{abstract}
Abstrak
Permasalahan pada sistem penyewaan dan pembayaran alat katering pada Viaa Wedding yaitu lambatnya pendataan barang dan customer dalam proses penyewaan dan pembayaran. Karna sistem yang diterapkan masih bersifat manual dan belum terkomputerisasi. Tujuan dibuatnya sistem informasi penyewaan dan pembayaran alat katering pada Viaa Wedding Berbasis Java untuk memudahkan proses penyewaan dan pembayaran alat katering serta mempercepat pencarian data customer, proses penyewaan dan pengembalian alat katering. Metode yang digunakan untuk merancang sistem informasi penyewaan dan pembayaran alat katering ini adalah dengan menggunakan metode analisis data observasi lapangan dan menggunakan metode kuantitatif dengan Java dan MySQL. Selain itu peneliti juga menggunakan metode wawancara untuk mendapatkan data yang lebih lengkap. Sehingga dapat disimpulkan bahwa hasil penelitian ini adalah sistem terkomputerisasi yang dapat memudahkan bagian administrasi dalam melakukan penyewaan dan pembayaran serta pembuatan laporan yang lebih cepat dan akurat.
\end{abstract}

Kata Kunci: Perancangan Sistem Informasi, Penyewaan dan Pembayaran, Alat Katering.

\begin{abstract}
The problem with the rental system and payment of catering equipment on Viaa Wedding is the slow collection of goods and customers in the rental and payment process. Because the system applied is still manual and has not been computerized. The purpose of the creation of a catering tool rental and payment information system on Java-based Viaa Wedding to facilitate the process of leasing and payment of catering tools and accelerate the search of customer data, rental process and return of catering tools. The method used to design this catering tool rental and payment information system is to use field observation data analysis methods and use quantitative methods with Java and MySQL. In addition, researchers also use interview methods to get more complete data. It can be concluded that the results of this study are computerized systems that can facilitate the administration in conducting rentals and payments and the creation of faster and accurate reports.
\end{abstract}

Keywords: Information System Design, Rental and Payment, Catering Equipment.

\section{PENDAHULUAN}

Perkembangan dunia teknologi sudah berjalan dengan begitu pesatnya dan banyak dari hasil perkembangan teknologi itu digunakan diberbagai bidang kehidupan mulai dari perkerjaan yang sederhana sampai proyek-proyek besar yang kompleks. Komputer dapat mengelola berbagai data baik secara manual maupun menggunakan sebuah sistem yang sesuai degan jenis perkerjaan yang dilakukan, dan dengan adanya komputer sistem tesebut dapat selalu dikembangkan. Pengolahan data yang cangih dan pesat, komputerisasi merupakan suatu alternatif tepat yang dibutuhkan untuk seorang pemimpin dalam suatu organisasi atau instalasi membantu instalasi dalam mengolah data. Kebutuhan akan informasi yang akurat dan tepat untuk penyajian data sangat diperlukan oleh suatu organisasi atau prusahaan. Viaa Wedding bergerak dalam bidang penyewaan dan pembayaran alat katering untuk acara seperti pesta pernikahan, pesta ulang tahun, dan lain-lain. Sayangnya akses pinjam meminjam barang ataupun penyewaan barang fisik yang sifatnya langsung dari orang ke 
orang yang sangat terbatas dan sangat tergantung dengan relasi yang dimiliki. Membangun layanan penyewaan barang berbentuk fisik juga membutuhkan biaya yang tidak sedikit. karena itu, jumlah layanan semacam ini masih sangat terbatas. Kondisi ini sangat membingungkan orang-orang yang ingin menyewa ataupun meminjam barang, selain itu, hingga saat ini media peminjaman maupun penyewaan barang yang memiliki sumber daya yang cukup luas juga masih belum ada.

Rumusan masalah dalam penelitian ini yaitu pada sistem penyewaan dan pembayaran alat katering pada Viaa Wedding yaitu lambatnya pendataan barang dan customer dalam proses penyewaan dan pembayaran. Karna sistem yang diterapkan masih bersifat manual dan belum terkomputerisasi. Tujuan dari penelitian ini yaitu membangun sistem informasi penyewaan dan pembayaran alat katering pada Viaa Wedding Berbasis Java untuk memudahkan proses penyewaan dan pembayaran alat katering serta mempercepat pencarian data customer, proses penyewaan dan pengembalian alat katering. Perancangan adalah tahap pembuatan spesifikasi mengenai arsitektur program, gaya, tampilan dan kebutuhan material atau bahan untuk program (Binanto, 2010). Sistem adalah suatu jaringan kerja dari prosedur-prosedur yang saling berhubungan, berkumpul bersama-sama untuk melakukan kegiatan atau untuk melakukan sasaran tertentu (Hutahaean, 2014). Java adalah salah satu dari sekian banyak bahasa pemograman yang dapat dijalankan di berbagai sistem operasi termasuk telepon genggam (Nofriadi, 2015). Hasil penelitian ini adalah sistem terkomputerisasi yang dapat memudahkan bagian administrasi dalam melakukan penyewaan dan pembayaran serta pembuatan laporan yang lebih cepat dan akurat.

\section{PENELITIAN RELEVAN}

Penelitian yang dilakukan oleh (Bachtiar, 2012) dengan judul Rancang Bangun Sistem Informasi Penyewaan dan Maintenenance Alat-alat Pesta Pada Razka Jaya Rental Sebagai sarana untuk memudahkan penyewaan dan pembayaran agar menimalisir terjadinya kesalahan . Penelitian yang dilakukan oleh (Andri, 2012) dengan judul Rancang Bangun Aplikasi Pemesanan Tiket Bus P.O Budiman Berbasis Dekstop. Penelitian ini bertujuan untuk meminimalkan kesalahan dalam pengelolaan data dan transaksi.

\section{METODE PENELITIAN}

Dalam melakukan penelitian senantiasa diperlukan suatu metode penelitian yang sesuai dengan pokok permasalahan yang akan di teliti, sedangkan penelitian itu sendiri, menurut (Ridwan, 2012), adalah "suatu metode yang digunakan dalam penelitian yang dapat berbetuk metode penelitian survey, eksperimen, naturalistic, policy resarch (penelitian tindakan), evaluasi dan sejarah". Tujuan dari metode ini adalah untuk menentukan seberapa jauh suatu gejala berlaku umum yang bermaksud untuk membandingkan gejala atau kasus tersebut dengan gejala serupanya.

\section{Metode Pengumpulan Data}

1. Studi kepustakaan

Studi kepustakaan bertujuan untuk mempelajari dan memahami dasar teori yang berhubungan dengan analisa kebutuhan yang telah dilakukan.

2. Observasi

Menurut (Sugiono, 2015), observasi merupakan kegiatan pemuatan penelitian terhadap suatu objek. Apabila dilihat pada proses pelaksanaan pengumpulan data, observasi dibedakan menjadi partisipan dan non-partisipan. Jenis observasi yang digunakan pada penelitian ini adalah observasi non-partisipan. Dalam melakukan observasi, peneliti memilih hal-hal yang diamati dan mencatat hal-hal yang berkaitan dengan penelitian.

3. Wawancara

Menurut (Subagyo, 2011), suatu kegiatan dilakukan untuk mendapatkan informasi secara langsung dengan mengungkapkan pertanyaan-pertanyaan pada para responden. wawancara bermakna berhadapan langsung antara interview dengan responden, dan kegiatannya dilakukan secara lisan. 


\section{HASIL DAN PEMBAHASAN}

Data Flow Diagram atau dalam bahasa Indonesia menjadi Diagram Alir Data (DAD) adalah refresentasi grafik yang menggambarkan aliran informasi dan transformasi informasi yang diaplikasikan sebagai data yang mengatur dari masukan (input) dan keluaran (output) (Sukamto\&Shalahuddin, 2014). DFD tidak sesuai untuk memodelkan sistem yang menggunakan pemograman berorientasi objek. Berikut ini gambar diagram alir data dalam diagram konteks yang diusulkan :

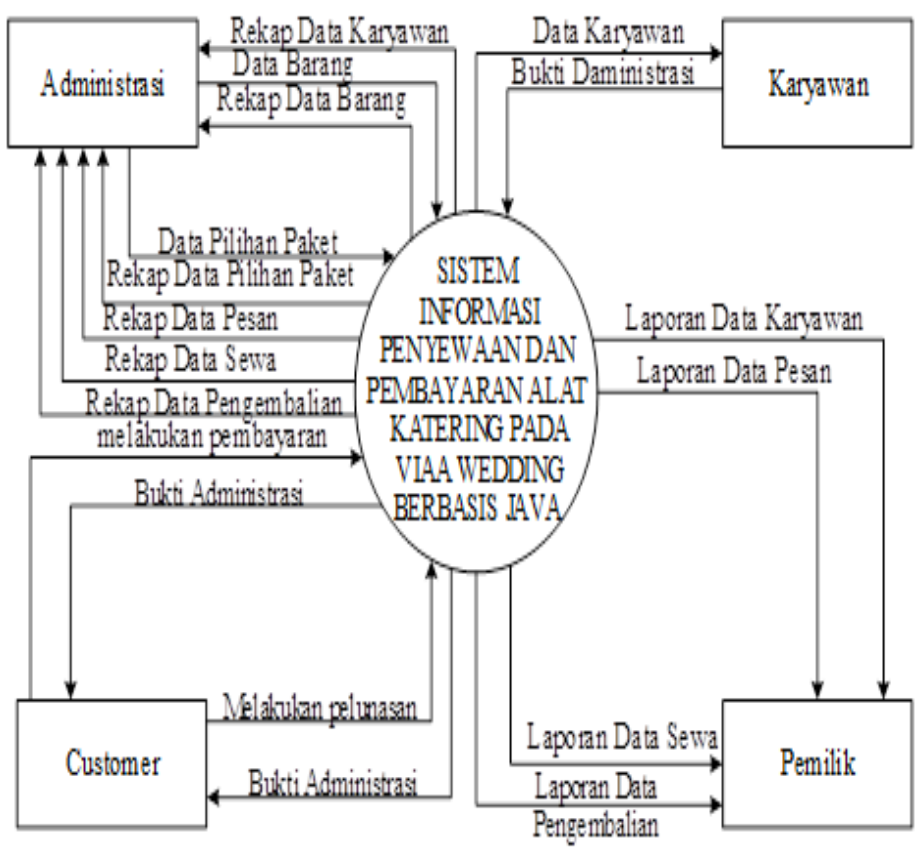

Gambar 1. Diagram Konteks

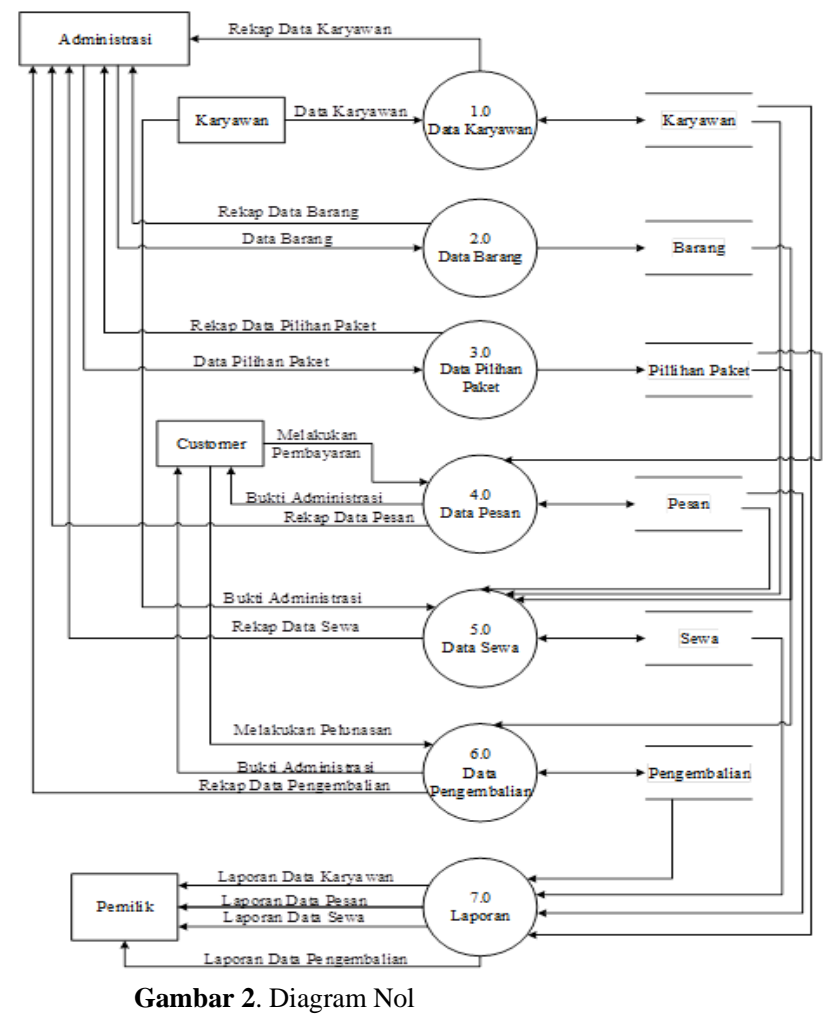




\section{Tampilan Layar}

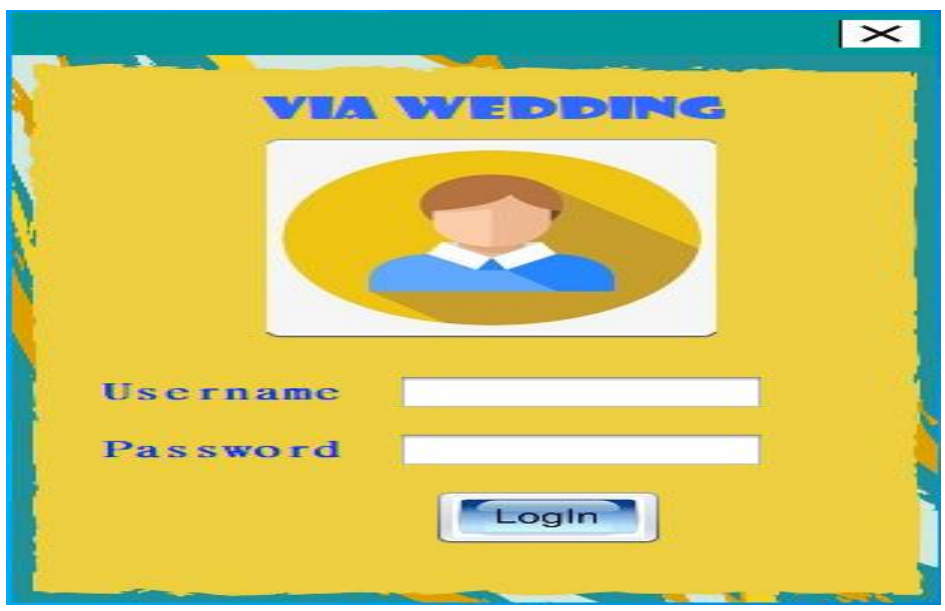

Gambar 3. Tampilan Layar Login

Tampilan layar login ini adalah akses untuk masuk ke aplikasi, setiap akses diarahkan untuk memasukan username dan password lalu klik login. Jika berhasil masuk maka akan masuk ke menu utama.

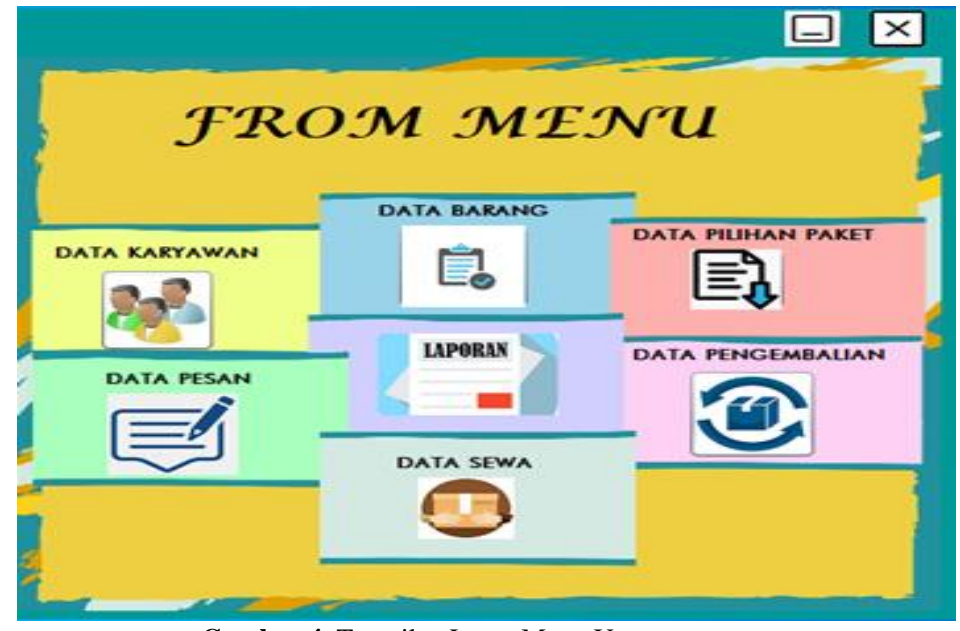

Gambar 4. Tampilan Layar Menu Utama

Tampilan layar menu utama terdiri dari data karyawan, data barang, data pilihan paket, data pesan, data sewa, data pengembalian dan laporan.

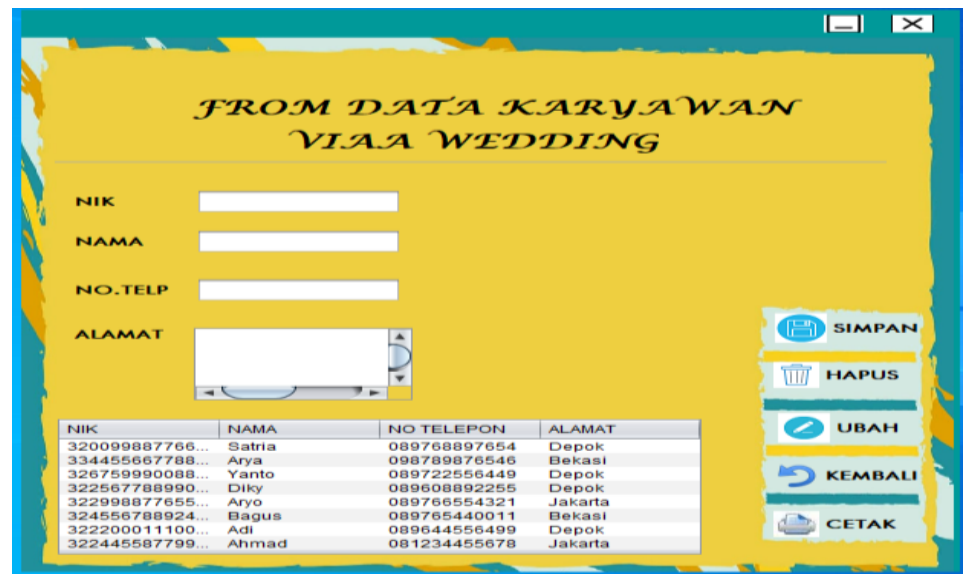

Gambar 5. Tampilan layar Data Karyawan 
Tampilan tampilan layar data karyawan dimana jika ada karyawan baru data tersebut akan diinput oleh bagian administrasi.

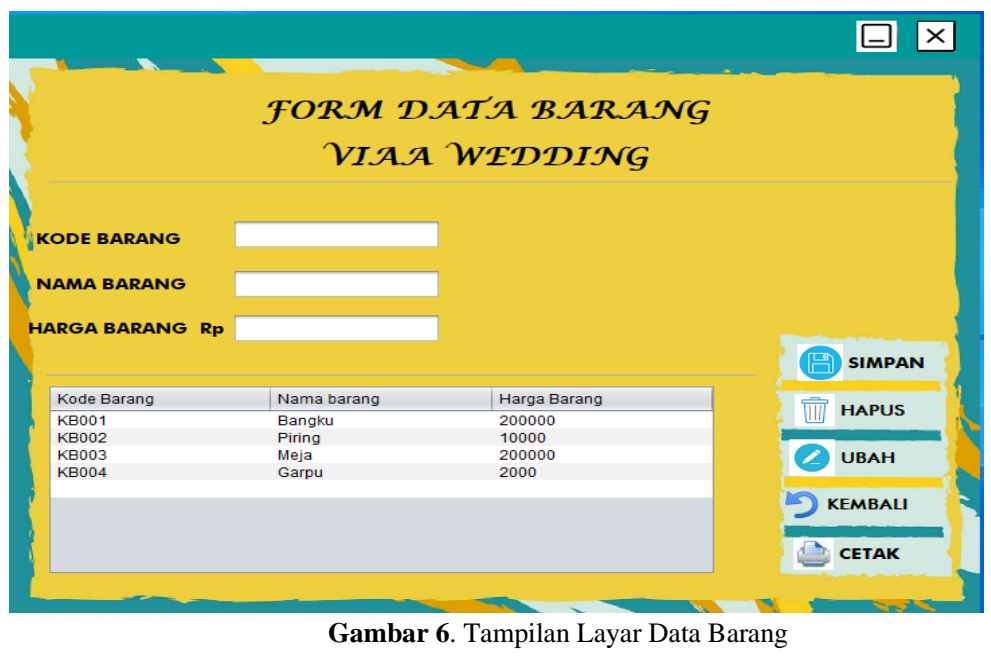

Tampilan data Barang merupakan tampilan untuk menginput data barang dan jika terjadi kehilangan barang, bagian administasi akan melihat data tersebut.

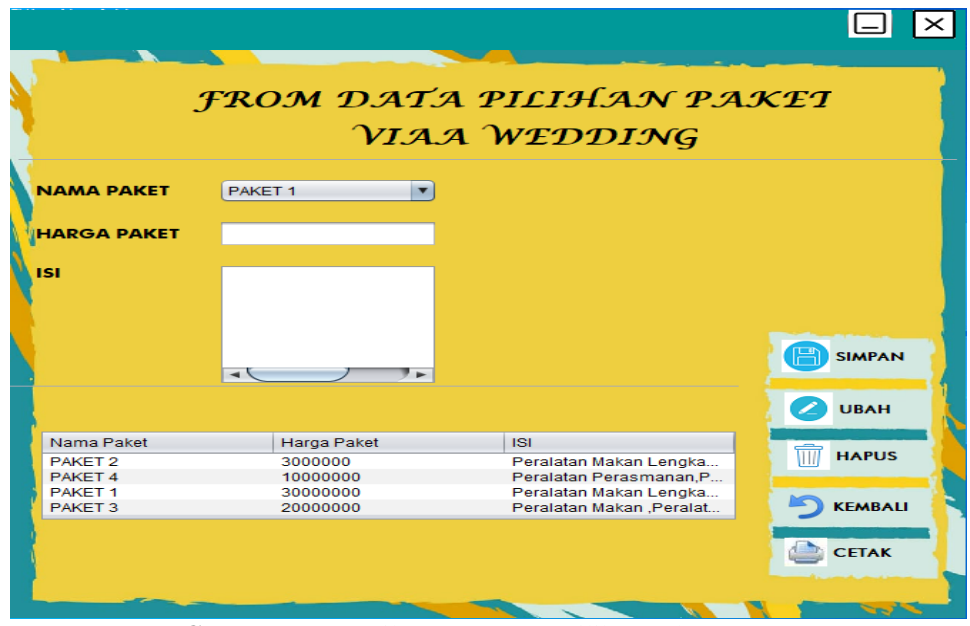

Gambar 7. Tampilan Layar Data Pilihan Paket

Tampilan data pilihan paket merupakan tampilan untuk menginput data paket apa saja yang tersedia pada Viaa Wedding.

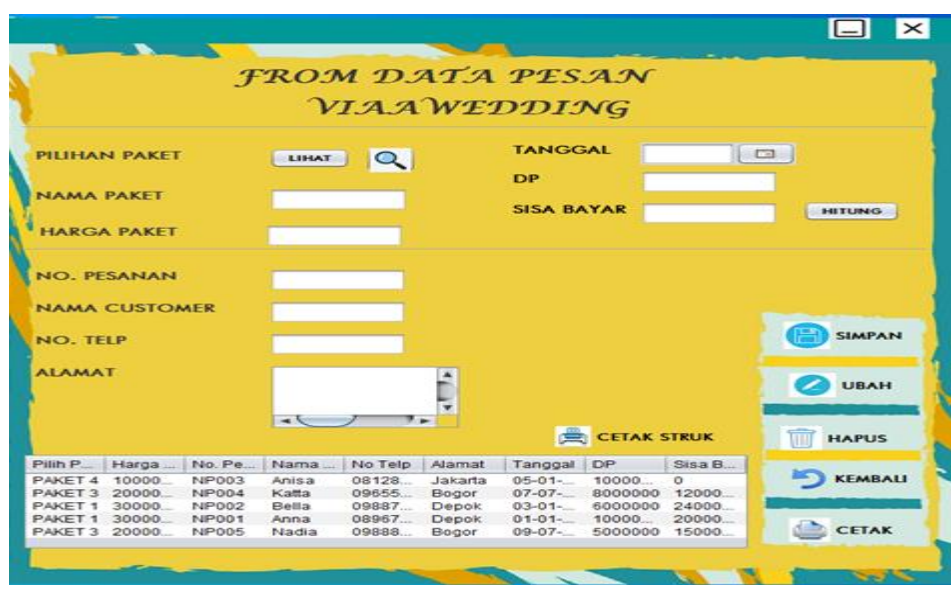

Gambar 8. Tampilan Layar Data Pesan 
Tampilan data pesan merupakan tampilan untuk customer melihat data-data paket apa saja yang ada di Viaa Wedding dan bagian administrasi menginput pesanan customer, setelah didata bagian administrasi akan memberikan data kepada karyawan untuk mempersiapkan paket yang sudah di pesan oleh customer.

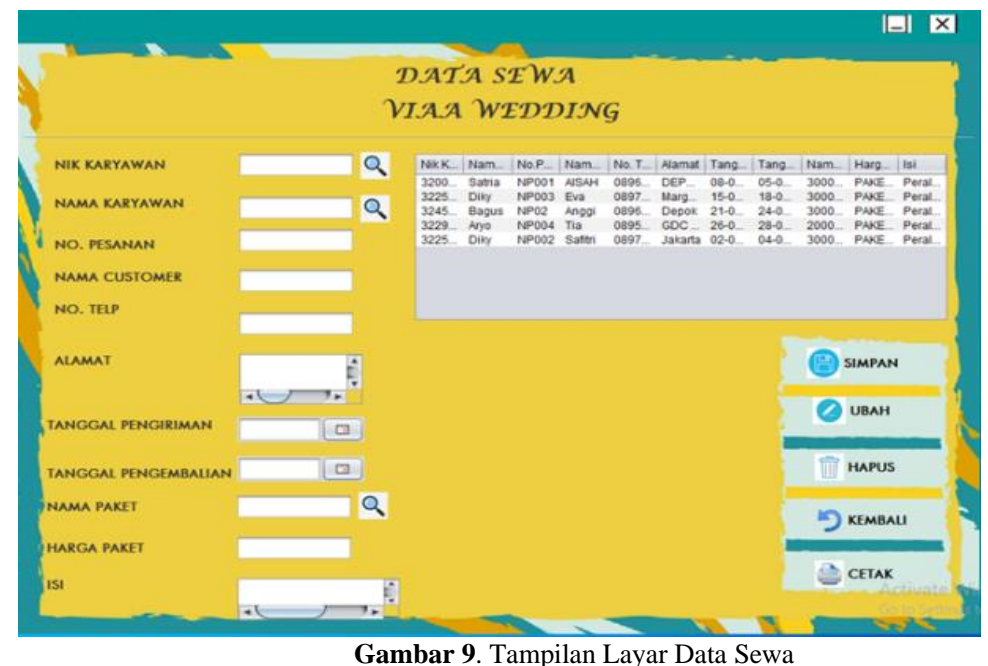

Gambar 9. Tampilan Layar Data Sewa

Tampilan data sewa merupakan tampilan untuk menginput data sewa yang sudah di pesan oleh customer, setelah alat-alat yang dipesan oleh customer sudah siap nantinya akan diinput oleh bagian administrasi. Setelah di data kemudian bagian administrasi akan memberikan data tersebut kepada karyawan untuk dipersiapkan dan diantar ke customer.

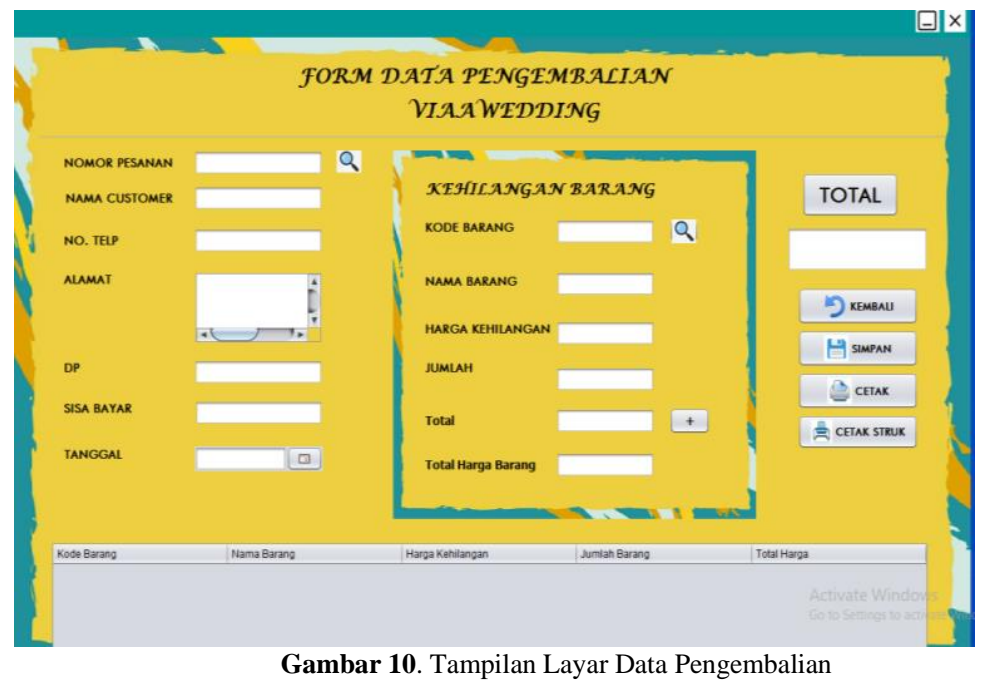

Tampilan data pengembalian merupakan tampilan untuk menginput data yang dikembalikan oleh customer dan mendata barang apa saja yg hilang. 


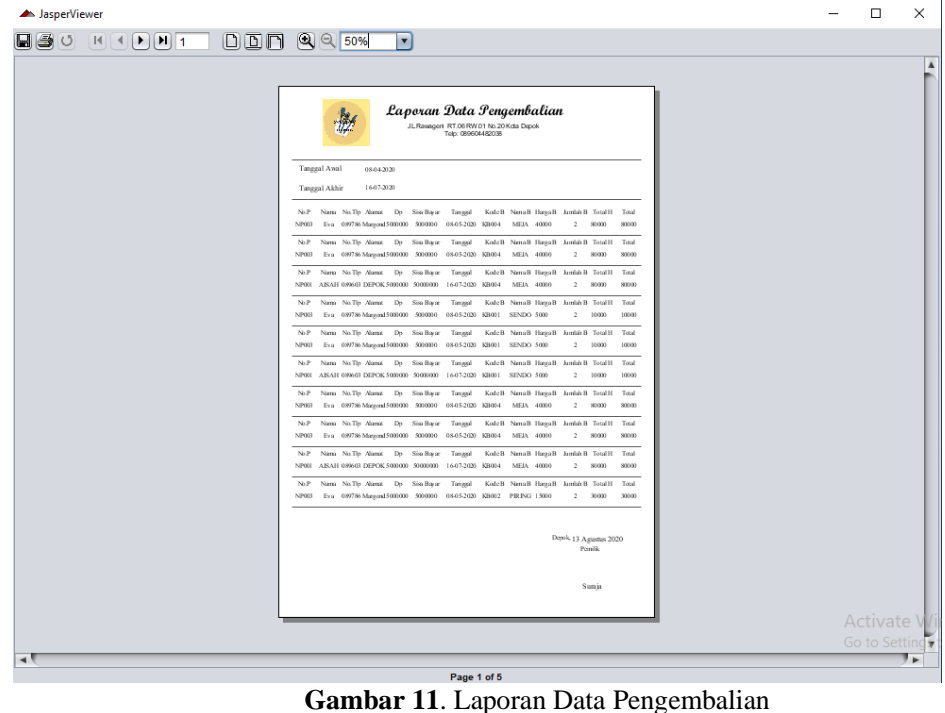

Pada laporan pengembalian, laporan ini diberikan kepada pemilik untuk digunakan sebagai bukti pada sistem pengelolaan Viaa Wedding. Laporan dapat dicetak sesuai periode yang diinginkan yaitu perhari, perbulan maupun pertahun.

\section{SIMPULAN}

Dengan dibuatnya Perancangan Sistem Informasi Penyewaan Dan Pembayaran Alat Katering Pada Viaa Wedding Berbasis Java, mempermudah para pekerja terutama bagian administrasi yang bertanggung jawab untuk pendataan yang ada di Viaa Wedding. Dengan adanya sistem yang terkomputerisasi semua kegiatan pendataan, transaksi dan laporan lebih cepat, tepat, efektif dan efesien.

\section{DAFTAR PUSTAKA}

Andri. (2012). Rancang Bangun Aplikasi Pemesanan Tiket Bus P.O Budiman Berbasis Dekstop. Jakarta: Universitas Indraprasta PGRI.

Bachtiar. (2012). Rancang Bangun Sistem Informasi Penyewaan dan Maintenenance Alat-alat Pesta Pada Razka Jaya Rental. Jakarta: Universitas Indraprasta PGRI.

Binanto, Iwan. (2010). Multimedia Digital - Dasar Teori dan Pengembangannya. Yogyakarta: Andi Publisher.

Hutahaean, Jeperson. (2014). Konsep Sistem Informasi. Yogyakarta: Deepublish.

Nofriadi. (2015). Java Fundamental dengan Netbeans 8.0.2. Yogyakarta: Deepublish.

P.Joko Subagyo. (2011). Metodologi Penelitian Dalam Teori Dan Praktek. Jakarta: Aneka Cipta

Ridwan. (2012). Metode \& Teknik Menyusun Proposal Penelitian. Bandung: Alfabeta.

Rosa dan Shalahuddin, M. (2015). Rekayasa Perangkat Lunak Terstruktur dan Beroroentasi Objek. Bandung: Informatika

Sugiyono. (2015). Metode Penelitian Kuantitatif dan R \& D. Bandung: Alfabeta

Sukamto. R. A., dan Shalahudin, M. (2014). Rekayasa Perangkat Lunak Terstruktur Dan Beroroentasi Objek. Bandung: Informatika 